\title{
Posteroanterior lumbar spine mobilizations in healthy female volunteers. Evaluation of pain to cold and pressure: crossover clinical trial*
}

\author{
Mobilizações póstero-anteriores na coluna lombar em voluntárias saudáveis. Avaliação da dor \\ ao frio e à pressão: ensaio clínico cruzado
}

Jhenifer Karvat ${ }^{1}$, Juliana Sobral Antunes ${ }^{1}$, Gladson Ricardo Flor Bertolini ${ }^{1}$

${ }^{*}$ Received from the Laboratory for the Study of Injuries and Physiotherapeutic Resources, State University of Western Paraná (UNIOESTE), Cascavel, PR, Brazil.

\section{ABSTRACT}

BACKGROUND AND OBJECTIVES: Low back pain is a public health problem and among physiotherapeutic treatment modalities there are joint mobilizations, such as central posteroanterior joints. However, there is a gap with regard to mobilization of all lumbar vertebrae. So, this study aimed at evaluating the effects of different Maitland mobilizations levels, in all lumbar spine vertebrae, in healthy volunteers, to assess pain intensity to cold and pressure.

METHODS: This was a crossover clinical trial, with 15 female volunteers who received posteroanterior mobilizations, varying the level between I-IV. In one of the weeks, volunteers received no mobilization. Studied variables were pain intensity to cold and pain threshold to pressure, previous to mobilization (AV1), 5 (AV2) and 35 minutes after mobilization (AV3).

RESULTS: It was observed that 35 minutes after mobilization for levels II and III there has been significant pain intensity decrease to cold as compared to AV1, what was also true for levels III and IV as compared to AV2. There have been no significant differences in pressure threshold evaluation.

CONCLUSION: Mobilizations have produced as from LII significant decrease in pain intensity to cold, but there has been no effect with regard to pain to pressure.

Keywords: Physiotherapy modalities, Therapy with exercises, Spine.

\section{RESUMO}

JUSTIFICATIVA E OBJETIVOS: A dor lombar é um problema de saúde pública e dentre as formas de tratamento fisioterapêutico são utilizadas as mobilizações articulares, como as póstero-anteriores centrais. Contudo, há uma lacuna com

1. State University of Western Paraná, Cascavel, PR, Brazil.

Submitted in September 10, 2012.

Accepted for publication in January 14, 2014

Conflict of interests: none.

Correspondence to:

Gladson Ricardo Flor Bertolini

Rua Universitária, 2069 - Jardim Universitário

85819-110 Cascavel PR, Brasil.

E-mail: gladson_ricardo@yahoo.com.br

(C) Sociedade Brasileira para o Estudo da Dor relação à mobilização de todas as vértebras lombares. Assim, o objetivo deste estudo foi analisar os efeitos de diferentes graus das mobilizaçóes de Maitland, em todas as vértebras da coluna lombar, em voluntários saudáveis, avaliando a intensidade de dor ao frio e à pressão.

MÉTODOS: O estudo caracterizou-se como clínico e cruzado e composto por 15 voluntárias que receberam mobilizaçóes póstero-anteriores, variando-se o grau entre I-IV e também em uma das semanas não receberam mobilização. As variáveis analisadas foram a intensidade de dor ao frio e o limiar de dor à pressão, prévio à mobilização (AV1), cinco (AV2) e 35 minutos após a mobilização (AV3).

RESULTADOS: Foi possível observar que após 35 minutos da mobilização para os graus II e III houve diminuição significativa da intensidade de dor ao frio ao comparar com AV1, o que também ocorreu para os graus III e IV ao comparar com AV2. Na avaliação do limiar de pressão não houve diferenças significativas.

CONCLUSÃO: As mobilizaçôes produziram a partir do grau II, redução significativa na intensidade de dor ao frio, mas não houve efeito com relação à dor à pressão.

Descritores: Coluna vertebral, Modalidades de fisioterapia, Terapia por exercício.

\section{INTRODUCTION}

Low back pain (LBP) is considered a global public health problem, generating significant social and health costs. There is a variety of physiotherapeutic approaches being most common the use of manual therapy with mobilizations and manipulations, electric stimulation and guidance ${ }^{1}$.

There are manual therapy techniques which are applied for diagnosis and management of joint mobility. So, physiotherapists using manual techniques correlate the findings of the exam to the nature and distribution of symptoms to reach a diagnosis and be able to select the most adequate treatment ${ }^{2}$. These manual techniques may be effective to control pain because skin touch may be a powerful means to modulate pain, and velocity of proprioceptive stimuli may help the inhibition of painful stimuli in the central nervous system (CNS) ${ }^{3}$.

Many manual therapy techniques, for being associated to the application of loads through physiotherapists' hands, depend 
on training and manual perception of each professional. A well-known manual therapy method is Maitland joint mobilization. This method involves a series of maneuvers used to evaluate and treat musculoskeletal system disorders. It consists in applying oscillatory loads to produce accessory intra-joint movement. This method divides loads application in levels of movement. However, such levels are defined in qualitative terms, which may lead to major variability in the application of loads for each level ${ }^{4}$.

Maitland mobilization levels I and II correspond to the application of oscillatory movements, with slow rhythm in the beginning of accessory joint movement amplitude, free from the resistance offered by tissues, and are indicated in cases of painful joint processes. Levels III and IV are maneuvers characterized by oscillatory movements at the end of accessory movement amplitude or as from periarticular tissues resistance ${ }^{5}$. Load imposed during maneuvers levels III and IV promotes viscoelastic adaptation of connective tissues, thus being indicated to recover accessory movements when there is restriction for such movement ${ }^{6}$.

One joint mobilization technique used to evaluate and treat spinal disorders is the central posteroanterior (PA) pressure technique. Here, the evaluator through the pisiform bone applies oscillatory load on the spinal process of one vertebra of a patient in the prone position. Although there are studies using PA mobilization on the lumbar spine, there is a gap with regard to mobilization of all vertebrae of this segment.

This study aimed at evaluating the effect of different levels of Maitland mobilizations in all lumbar spine vertebrae, in healthy volunteers, by evaluating pain intensity to cold and pressure.

\section{METHODS}

This is a crossover and transversal clinical trial. Sample was composed of 15 young, adult, female volunteers, students of the State University of Western Paraná (UNIOESTE), Cascavel campus, age $21.27 \pm 0.88$ years, height $1.67 \pm 0.06$ meters and weight $57.93 \pm 4.83 \mathrm{~kg}$. Sample size was calculated based on previous studies with the use of pressure dolorimeter for a standard deviation of 4.5 and difference to be detected of $5 \mathrm{Kgf}$, with significance level of $5 \%$ and power of $85 \%$.

In the first contact, volunteers were explained about intentions and procedures, as well as were asked about their interest in participating in the research. After acceptance of volunteers and their signing of the Free and Informed Consent Term, evaluations and mobilization techniques were started. Volunteers should not present LBP (chronic and/or acute), spinal surgeries, local sensory disorders and/or in lower limbs, infections, gestation and recent trauma. They should have their sensitivity preserved and should attend to relevant moments and dates.

\section{Evaluation moments}

Volunteers participated in the project once a week for five weeks. During four weeks they randomly received a different mobilization level (LI, LII, LIII, LIV) plus evaluations, and in one week they were just evaluated without mobilization (L0). Evaluations were carried out three times every day: premobilization moment (AV1), 5 (AV2) and 35 minutes after mobilization (AV3).

\section{Evaluation of pain intensity to cold}

Volunteer immersed the dominant foot up to the most distal region of the medial malleolus, in a container with water and ice at $5^{\circ} \mathrm{C} \pm 1$ for 30 minutes and temperature was controlled with Incoterm mercury thermometer. After 30 seconds the volunteer was asked about pain intensity by the visual analog scale (VAS). Such scale was a wood apparatus with a movable metal cursor on one side, where the volunteer would mark position between " 0 " (no pain) and "10" (maximum imaginable pain), and on the other side there was a ruler in the opposite direction allowing for the quantification in centimeters of pain indicated by participant.

\section{Evaluation of pain threshold to pressure}

To evaluate pain to pressure a pressure dolorimeter (Kratos $\left.{ }^{\circ}\right)$ was used, with capacity to produce up to $50 \mathrm{Kgf}$, with $1 \mathrm{~cm}^{2}$ circular tip, which was applied on the spinous process of the $3^{\text {rd }}$ lumbar vertebra soon after evaluation by VAS.

\section{Mobilization protocol}

Patients received central PA technique for mobilization in all lumbar spine spinous processes, for one minute each. Two therapists have performed mobilizations, however to prevent biases, there was no rotation between therapists, that is, they would mobilize always the same individual.

Volunteers remained in the prone position with arms along the body. Therapist remained at the left side and positioned left hand ulnar border, region of pisiform and hamate bones, in contact with the spinous process of the vertebra to be mobilized. Left hand was then reinforced by shell-shaped right hand with the approximation of thenar and hypothenar eminences over the radial surface of the other hand. So, leaving right middle, ring and little fingers between left index finger and thumb, and placing left index finger and thumb over left hand dorsum, stability was obtained by holding the palm of left hand between thenar eminence and right middle, ring and little fingers. Therapist's shoulders were in balance over the patient, with slightly flexed elbows.

The study was carried out during five weeks, being that in four weeks volunteers received interleaved levels of mobilization and in one week they were only randomly evaluated. For every week there were three randomly chosen volunteers for each subgroup. Mobilization levels were:

Level I - low amplitude movement close to initial route position;

Level II - high amplitude movement within the route. It may occupy any part of the route which is free from any muscle stiffness or spasm;

Level III - high amplitude movement, however within muscle stiffness or spasm at the end of amplitude; 
Level IV - low amplitude forced movement within muscle stiffness or spasm at the end of amplitude.

Volunteers received mobilizations soon after the first evaluation moment (AV1) and then they were evaluated as already described.

ANOVA test for repetitive measures with Bonferroni post-test were used for data analysis, considering significant $\alpha=5 \%$.

This study was approved by the Research Ethics Committee, State University of Western Paraná (UNIOESTE) under opinion 242/2011.

\section{RESULTS}

Pain intensity to cold, evaluated by VAS, has shown pain intensity decrease only in the last evaluation, when mobilization was carried out as from LII. There were no statistically significant differences among groups (Table 1).

Table 1. Pain intensity to cold, according to visual analog scale, in all levels of the three evaluations

\begin{tabular}{llccc}
\hline & Levels & AV1 & AV2 & AV3 \\
\hline & L0 & $3.94 \pm 2.09$ & $4.19 \pm 2.17$ & $3.33 \pm 2.64$ \\
Visual & LI & $4.95 \pm 3.08$ & $4.79 \pm 3.08$ & $3.70 \pm 2.86$ \\
analog & LII & $4.70 \pm 2.98$ & $4.50 \pm 2.64$ & $3.36 \pm 2.58^{*}$ \\
scale & LIII & $4.75 \pm 2.37$ & $4.65 \pm 2.72$ & $2.84 \pm 2.13^{* \circ}$ \\
& LIV & $3.90 \pm 2.35$ & $4.36 \pm 2.69$ & $2.86 \pm 2.42^{\circ}$ \\
\hline
\end{tabular}

${ }^{*}$ Significant difference within group, when comparing with AV1; ${ }^{\circ}$ Significant difference, within group, when comparing with AV2.

\section{Pain threshold to pressure}

During evaluation of pain threshold to pressure, no group has shown significant differences (Table 2). There were also no significant differences among groups.

Table 2. Results of pain threshold to pressure on L3 according to levels used during three evaluations

\begin{tabular}{llccc}
\hline & Levels & AV1 & AV2 & AV3 \\
\hline \multirow{4}{*}{$\begin{array}{l}\text { Pain } \\
\text { threshold }\end{array}$} & LO & $774.0 \pm 400.4$ & $604.7 \pm 455.0$ & $596.7 \pm 333.5$ \\
& LI & $522.0 \pm 259.0$ & $620.7 \pm 384.6$ & $519.3 \pm 319.7$ \\
& LIII & $630.7 \pm 383.2$ & $544.7 \pm 326.0$ & $485.3 \pm 238.4$ \\
& LIV & $638.7 \pm 359.2$ & $591.3 \pm 329.9$ & $588.0 \pm 327.3$ \\
\hline
\end{tabular}

\section{DISCUSSION}

Manual therapy is effective to treat $\mathrm{LBP}^{7}$. During evaluation, therapists look for signs of spinal stiffness of people with low back pain aiming at treating $i^{8}$. However, there are controversies with regard to stiffness as predictor of clinical results such as pain and incapacity ${ }^{9}$. However, notwithstanding controversies, spinal mobilizations have as major results the in- hibition of pain induced by mechanical stimuli, which may occur by creating long term depression of CNS synaptic function, in addition to improving lumbar spine movement amplitude $^{10,11}$. Our study has used the PA technique in the whole lumbar segment, which has decreased pain intensity to cold. A previous study, also using PA mobilization, but in patients with LBP, has shown that mobilization may decrease pain intensity when patients actively move, and the protocol used was three one-minute repetitions and mobilization force magnitude was selected by the therapist according to the patient ${ }^{12}$. Similarly, it was observed in our study that pain intensity to cold was decreased with mobilizations as from level II, fact which was not observed both for control group (G0) and level II. Precise pain relief mechanisms are still not established, but possible explanations are theories such as gates and descending suppression mediated by periaqueductal gray matter. A study using PA mobilization on L3, with pressure variations between 50 and $200 \mathrm{~N}$, which were alternated from large to semi-static oscillations, has observed decreased pain threshold to pressure in all variations ${ }^{13}$.

This result was not observed in the evaluation of pain threshold to pressure in our study, however it is worth highlighting that all lumbar vertebrae were mobilized, which might have generated discomfort caused by pressure in more than one segment. Also, one have to take into consideration that, in our study, mobilizations were performed by two students who, in spite of having been trained, had little experience with the technique, which even for experienced therapists, according to studies, has poor reliability of mobilization levels performance 5,14 . Another limitation of our study was that it was a crossover study, which might have generated the loading effect, although in attempt to decrease such effect, there was a 7-day interval between mobilizations.

So, it is suggested that new studies could be carried out with more experienced therapists and evaluating mobilizations in more than one segment. We also stress that the lack of changes in cold-induced pain for level I does not mean that this could not produce hypoalgesic effects ${ }^{15}$, but for individuals without previous pain such stimulus was insufficient to generate minimizing effects. So, studies with mobilizations in more than one segment in acute and chronic low back pain patients are relevant.

\section{CONCLUSION}

Oscillatory mobilizations on lumbar vertebrae of healthy individuals have produced, as from LII, significant decrease in pain intensity to cold, but there has been no effect with regard to pain to pressure.

\section{ACKNOWLEDGMENTS}

To the National Council of Scientific and Technological Development (CNPq) and to Araucária Foundation for the support with scientific initiation scholarships in the Affirmative Actions modality. 


\section{REFERENCES}

1. Gracey JH, McDonough SM, Baxter GD. Physiotherapy management of low back pain: a survey of current practice in Northern Ireland. Spine. 2002;27(4):406-11.

2. van de Veen EA, de Vet HC, Pool JJ, Schuller W, de Zoete A, Bouter LM. Variance in manual treatment of nonspecific low back pain between orthomanual physicians, manual therapists, and chiropractors. J Manipulative Physiol Ther. 2005;28(2):108-16.

3. Gosling AP. Mecanismos de açấo e efeitos da fisioterapia no tratamento da dor. Rev Dor. 2013;13(1):65-70.

4. Chiradejnant A, Latimer J, Maher CG. Forces applied during manual therapy to patients with low back pain. J Manipulative Physiol Ther. 2002;25(6):362-9.

5. Snodgrass SJ, Rivett DA, Robertson VJ. Manual forces applied during cervical mobilization. J Manipulative Physiol Ther. 2007;30(1):17-25.

6. Hsu A, Ho L, Chang J, Chang GL, Hedman T. Characterization of tissue resistance during a dorsally directed translation mobilization of the glenohumeral joint. Arch Phys Med Rehabil. 2002;83(3):360-6

7. Slater SL, Ford JJ, Richards MC, Taylor NF, Surkitt LD, Hahne AJ. The effectiveness of sub-group specific manual therapy for low back pain: a systematic review. Man Ther. 2012;17(3):201-12.
8. Kumar S. Posteroanterior spinal stiffness at T5, T10, and L3 levels in normal subjects. PMR. 2012;4(5):342-8.

9. Ferreira ML, Ferreira PH, Latimer J, Herbert RD, Maher C, Refshauge K. Relationship between spinal stiffness and outcome in patients with chronic low back pain. Man Ther. 2009;14(1):61-7.

10. Zusman M. Mechanism of mobilization. Phys Ther Rev. 2011;15(4):233-6.

11. Sato T, Koumori T, Uchiyama Y. Preliminary study of the immediate effect of spinal segmental side bending mobilization on improves lumbar range of motion. J Phys Ther Sci. 2012;24(5):431-4.

12. Goodsell M, Lee M, Latimer J. Short-term effects of lumbar posteroanterior mobilization in individuals with low-back pain. J Manipulative Physiol Ther. 2000;23(5):332-42.

13. Krouwel O, Hebron C, Willett E. An investigation into the potential hypoalgesic effects of different amplitudes of PA mobilisations on the lumbar spine as measured by pressure pain thresholds (PPT). Man Ther. 2010;15(1):7-12

14. Snodgrass SJ, Rivett DA, Robertson VJ. Manual forces applied during posterior-toanterior spinal mobilization: a review of the evidence. J Manipulative Physiol Ther. 2006;29(4):316-29.

15. Martins DF, Bobinski F, Mazzardo-Martins L, Cidral-Filho FJ, Nascimento FP, Gadotti VM, et al. Ankle joint mobilization decreases hypersensitivity by activation of peripheral opioid receptors in a mouse model of postoperative pain. Pain Med. 2012;13(8):1049-58. 